\title{
PENGARUH LIFESTYLE, PERCIEVED EASE OF USE DAN KEPERCAYAAN TERHADAP KEPUTUSAN PEMBELIAN PADA TOKO PAKAIAN ONLINE
}

\author{
Rika Wahyuni' Hadi Irfani \\ Universitas Putra Indonesia "YPTK" Padang \\ e-mail:rikawahyuni070685@gmail.com, hadi.irfani.st@gmail.com
}

\begin{abstract}
The aim of this study was to determine the influence Lifestyle, Percieved Ease Of Use and Trust on Purchasing Decisions on Online Fashion Shop. This reserch is quantitative descriptive data and causal analysis, respondents surveyed in this study amounted to 50 people who have made a purchasing on online fashion shop by using purposive sampling. Then carried out analysis to the data obtained by using double regression analysis. Lifestyle significantly influence Purchasing Decisions on Online Fashion Shop, Percieved Ease Of Use significantly influence Purchasing Decisions on Online Fashion Shop, Trust significantly influence Purchasing Decisions on Online Fashion Shop. Lifestyle, Percieved Ease Of Use and Trust significantly influence Purchasing Decisions on Online Fashion Shop amounted to $78 \%$. Where as the remainder about 22\% described by other variable is not used within this research.
\end{abstract}

Keywords: Lifestyle, Percieved Ease Of Use, Trust, Purchasing Decisions

\begin{abstract}
ABSTRAK
Tujuan dari penelitian ini adalah untuk mengetahui pengaruh Lifestyle, Percieved Ease Of Use dan kepercayaan terhadap Keputusan Pembelian pada Toko Pakaian online. Penelitian ini merupakan penelitian kuantitatif dengan analisis data deskriptif dan kausal, responden yang diteliti dalam penelitian ini berjumlah 50 orang yang pernah melakukan pembelian pada toko pakaian online yang diperoleh dengan menggunakan teknik purposive sampling. Kemudian dilakukan analisis terhadap data yang diperoleh dengan menggunakan analisis linear berganda. Lifestyle berpengaruh signifikan terhadap Keputusan Pembelian pada Toko Pakaian online, Percieved Ease Of Use berpengaruh signifikan terhadap Keputusan Pembelian pada Toko Pakaian Online dan Kepercayaan berpengaruh signifikan terhadap Keputusan Pembelian pada Toko Pakaian Online. Lifestyle, Percieved Ease Of Use dan Kepercayaan berpengaruh signifikan terhadap Keputusan Pembelian pada Toko Pakaian Online sebesar 78\%. Sedangkan sisanya 22\% dijelaskan oleh variabel lain yang tidak diteliti dalam penelitian ini.
\end{abstract}

Kata Kunci: Lifestyle, Percieved Ease Of Use, Kepercayaan, Keputusan Pembelian

\section{PENDAHULUAN}

Toko online merupakan tempat dilakukannya aktivitas perdagangan atau jual beli barang yang dikenal dengan istilah belanja online, yang terhubungan ke dalam sebuah jaringan (Sarwandi, 2016). Aktivitas berbelanja online diminati oleh konsumen karena dianggap mempermudah konsumen saat berbelanja. Melalui berbelanja online pembeli dapat melihat berbagai produk yang ditawarkan melalui web yang dipromosikan oleh penjual. Menurut Wardoyo dan 
Andini (2017), aktivitas belanja online di Indonesia berkembang dengan pesat dan cepat sejak awal 2012. Pembelian online sangat high risk dalam pembayaran yang dilakukan sebelum pengiriman barang, namun dengan berbagai testimoni yang dimunculkan oleh pihak penjual dapat meyakinkan pembeli.

Berkembangnya e-commerce beserta kemudahan dalam pembayaran mempengaruhi keputusan pembelian melalui situs belanja online, diantaranya pada ibu-ibu rumah tangga. Hasil riset yang dilakukan oleh SWA mengungkap 66\% dari para konsumen Indonesia berbelanja produk online adalah kategori ibu dan anak (SWA, 2018). Pada ibu-ibu rumah tangga di Kecamatan Lubuk Begalung mengambil keputusan pembelian pada toko pakaian online tentu saja menuntut kecermatan, bersikap pintar, efisien dan efektif terutama dalam memilih produk yang diinginkan.

Ada beberapa faktor yang digunakan ibu-ibu rumah tangga dalam melakukan pembelian melalui situs belanja online, diantaranya gaya hidup, kepercayaan dan percieved ease of use. Kotler dan Keller (2012:192), mendefinisikan gaya hidup sebagai pola hidup konsumen dalam melakukan pembelian, dipengaruhi oleh karakteristik gaya hidup yaitu aktivitas, minat, dan opininya, dimana seseorang melakukan kegiatan dalam memenuhi kebutuhannya seperti pekerjaan, hobi, belanja, dan hiburan. Penelitian Wardoyo dan Andini (2017) mengungkapkan bahwa gaya hidup berpengaruh positif terhadap keputusan pembelian. Hasil wawancara dengan ibu-ibu rumah tangga di Kecamatan Lubuk Begalung, tren berbelanja melalui situs online cenderung mereka lakukan untuk perubahan penampilan mereka khususnya pakaian yang menurut mereka dapat membuat terlihat lebih menarik dan tidak ketinggalan model dari orang lain.

Percieved ease of use didefinisikan sebagai keyakinan akan kemudahan penggunaan, yaitu tingkatan dimana user percaya bahwa teknologi/sistem tersebut dapat digunakan dengan mudah dan bebas dari masalah (Davis, 1989). Ini dapat disimpulkan bahwa percieved ease of use merupakan sesuatu kepercayaan tentang proses pengambilan keputusan. Jika pelanggan percaya sistem informasi mudah digunakan maka dia akan menggunakannya. Sebaliknya jika pelanggan percaya bahwa sistem informasi tidak mudah digunakan maka dia tidak akan menggunakannya. Namun dari sekian banyaknya kemudahan penggunaan yang ditawarkan situs belanja online, dari hasil wawancara dengan ibu-ibu rumah tangga di Kecamatan Lubuk Begalung Padang masih terdapat beberapa permasalahan saat menggunakan aplikasi pada situs belanja online seperti ketidakpahaman pelanggan saat proses pemesanan dan kesulitan saat proses pembayaran melalui mobile banking sebagai alat pembayaran pada situs belanja online.

Mowen (2011:312), menyatakan kepercayaan adalah semua pengetahuan yang dimiliki oleh konsumen dan semua kesimpulan yang dibuat konsumen tentang objek, atribut, dan manfaatnya. Baskara dan Hariyadi dalam Wardoyo dan Andini (2017), mengungkap dalam penelitiannya bahwa faktor yang sangat penting yang bisa mempengaruhi pembelian online adalah kepercayaan. Kepercayaan menjadi alat untuk meningkatkan keyakinan konsumen dalam menentukan keputusan untuk membeli sebuah produk melalui situs jejaring sosial. Semakin maraknya kejahatan yang terjadi pada internet berupa pembobolan, penipuan, dan lain sebagainya faktor kepercayaan menjadi hal yang sangat berperan penting dalam transaksi belanja online. Konsep ini menjadikan pembeli 
percaya terhadap produk yang ditawarkan oleh penjual melalui online sesuai dengan yang ditampilkan dan dapat menjamin keamanan bertransaksi online. Keamanan berarti bahwa transaksi penjualan online dapat dipercaya oleh konsumen.

Adapun tujuan dari penelitian ini adalah untuk mengetahui pengaruh gaya hidup terhadap keputusan pembelian pada toko pakaian online, untuk mengetahui pengaruh percieved ease of use terhadap keputusan pembelian pada toko pakaian online, untuk mengetahui pengaruh kepercayaan terhadap keputusan pembelian pada toko pakaian online, untuk mengetahui pengaruh gaya hidup, percieved ease of use dan kepercayaan terhadap keputusan pembelian pada toko pakaian online.

\section{TINJAUAN LITERATUR}

Deavaj dkk, dalam Anggraeni dan Madiawati (2016) mendefinisikan keputusan pembelian dalam jaringan adalah pembelian yang dilakukan konsumen melalui proses alternatif dengan menggunakan media internet yang memiliki nilai manfaat yang lebih tinggi. Schiffman dan Kanuk (2009:112), keputusan pembelian merupakan suatu pilihan dari beberapa alternatif yang ada. Indikator keputusan pembelian secara online diambil dari Deavaj, dkk dalam Anggraeni dan Madiawati (2016), yakni: efisiensi pencarian waktu, value, dan interaksi.

Sumarwan (2011:57), menyatakan gaya hidup sering digambarkan dengan kegiatan, minat dan opini dari seseorang (activities, interests, and opinions). Gaya hidup seseorang biasanya tidak permanen dan cepat berubah. Seseorang mungkin dengan cepat mengganti model dan merek pakaiannya karena menyesuakan dengan perubahan hidupnya. Kusnandar dan Kurniawan (2018) mengungkapkan gaya hidup sebagai gambaran tingkah laku dan pola hidup seseorang yang diekspresikan dalam aktivitas, minat, dan opininya. Pendapat lainnya dikemukakan oleh Kotler dan Keller (2012:192), mengenai gaya hidup adalah pola hidup seseorang di dunia yang diekspresikan dalam aktivitas, minat, dan opininya. Gaya hidup menggambarkan keseluruhan diri seseorang dalam berinteraksi dengan lingkungannya. Gaya hidup menggambarkan seluruh pola seseorang dalam beraksi dan berinteraksi di dunia. Indikator gaya hidup dalam pembelian diambil dari Prasetijo dalam Kusnandar dan Kurniawan (2018), yakni: Activities (kegiatan), Interest (minat), dan Opinion (pendapat).

Menurut Thoha (2012:141-142), persepsi pada hakikatnya adalah proses kognitif yang dialami oleh setiap orang di dalam memahami informasi tentang lingkungannya, baik lewat penglihatan, pendengaran, penghayatan, perasaan, dan penciuman. Persepsi adalah proses dimana kita memilih, mengatur, dan menafsirkan masukan informasi untuk menciptakan gambaran yang berarti dari dunia (Kotler dan Keller, 2012:161-162). Percieved ease of use didefinisikan sebagai keyakinan akan kemudahan penggunaan yaitu tingkatan dimana user percaya bahwa teknologi/sistem tersebut dapat digunakan dengan mudah dan bebas dari masalah (Davis, 1989). Faktor kemudahan ini terkait dengan bagaimana operasional bertransaksi secara online. Kemudahan merupakan hal terpenting yang harus diperhatikan oleh para penyedia atau penjual online agar para konsumen dapat dengan mudah mengakses dan mengaplikasikan situs web belanja online tersebut untuk berbelanja. Indikator percieved ease of use diambil dari Davis (1989), yakni: mudah dipelajari (ease of learn), mudah dikontrol (controllable), jelas dan mudah dimengerti (clear and understandable), fleksibel 
(flexible), mahir (ease to become skillful), dan mudah untuk digunakan (ease to use).

Menurut Kotler dan Keller (2012:225), kepercayaan adalah kesediaan pihak perusahaan untuk mengandalkan mitra bisnis. Kepercayaan tergantung pada sejumlah faktor interpersonal dan antarorganisasi, seperti kompetensi perusahaan, integritas, kejujuran dan kebaikan. Kepercayaan adalah pengetahuan konsumen mengenai suatu objek, atributnya, dan manfaatnya. Berdasarkan konsep tersebut, maka pengetahuan konsumen sangat terkait dengan pembahasan sikap karena pengetahuan konsumen adalah kepercayaan konsumen. Kepercayaan konsumen atau pengetahuan konsumen menyangkut kepercayaan bahwa suatu produk memiliki berbagai atribut, dan manfaat dari berbagai atribut tersebut (Sumarwan, 2011:165-166). Pendapat Mowen (2011:312) kepercayaan adalah semua pengetahuan yang dimiliki oleh konsumen dan semua kesimpulan yang dibuat konsumen tentang objek, atribut, dan manfaatnya. Bertransaksi secara online memiliki kepastian dan informasi yang tidak simetris. Oleh karena itu jika konsumen medapatkan pengalaman yang baik saat bertransaksi secara online dan merasa yakin akan keamanannya ketika melakukan transaksi online ataupun belanja online di sebuah situs belanja online, maka konsumen cenderung untuk melakukan keputusan pembelian yang lebih tinggi pada situs belanja online tersebut. Indikator kepercayaan diambil Robbins dan Judge (2007:392), yakni: integritas, kompetensi dan konsistensi.

\section{METODE PENELITIAN}

Penelitian ini merupakan penelitian kausalitas dengan variabel independen yaitu Gaya Hidup $\left(\mathrm{X}_{1}\right)$, Percieved ease of use $\left(\mathrm{X}_{2}\right)$, Kepercayaan $\left(\mathrm{X}_{3}\right)$, kemudian variabel dependen dalam penelitian ini yaitu Keputusan Pembelian (Y). Populasi yaitu ibu rumah tangga di Kecamatan Lubuk Begalung Kota Padang yang melakukan pembelian pada toko pakaian online. Jumlah sampel yang diambil sebanyak 50 orang ditentukan dengan teknik purposive sampling. Untuk mendapatkan hasil dari penelitian yang dilakukan dan untuk menjawab hipotesis dilakuan uji analisis regresi linear berganda, uji t, uji F dan uji determinasi.

\section{HASIL DAN PEMBAHASAN}

\section{Hasil Uji Analisis Regresi Linear Berganda}

Analisis regresi linear berganda digunakan untuk melihat pengaruh variabel bebas Gaya Hidup $\left(\mathrm{X}_{1}\right)$, Percieved ease of use $\left(\mathrm{X}_{2}\right)$, Kepercayaan $\left(\mathrm{X}_{3}\right)$ terhadap variabel terikat Keputusan Pembelian (Y) yang dilakukan pada 50 responden yang pernah melakukan pembelian pada toko pakaian online.

\section{Tabel 1}

Hasil Persamaan Regresi Linear Berganda

\begin{tabular}{lccc}
\hline Model & B & t & Sig. \\
\hline Constant & 2,180 & 1,250 & 0,218 \\
Gaya Hidup & 0,393 & 4,171 & 0,000 \\
Percieved Ease Of Use & 0,152 & 3,206 & 0,002 \\
Kepercayaan & 0,215 & 2,586 & 0,013 \\
\hline
\end{tabular}

Sumber: Olah data output SPSS 21, 2019 
Berdasarkan pengolahan data tabel 1 maka dapat diperoleh persamaan regresi sebagai berikut:

$$
\mathrm{Y}=2,180+0,393 \mathrm{X}_{1}+0,152 \mathrm{X}_{2}+0,215 \mathrm{X}_{3}
$$

Persamaan diatas dapat diartikan sebagai berikut:

a. Nilai konstanta sebesar 2,180 menyatakan bahwa jika tidak ada kenaikan nilai dari variabel gaya hidup, percieved ease of use, kepercayaan maka nilai dari keputusan pembelian adalah 2,180.

b. Nilai koefisien regresi gaya hidup bersifat positif sebesar 0,393, artinya variabel gaya hidup memiliki hubungan searah dengan keputusan pembelian dan setiap pertambahan satu satuan gaya hidup akan berpengaruh terhadap meningkatnya keputusan pembelian pada toko pakaian online (Y) sebesar 0,393 .

c. Nilai koefisien regresi percieved ease of use bersifat positif sebesar 0,152 , artinya variabel percieved ease of use memiliki hubungan searah dengan keputusan pembelian dan setiap pertambahan satu satuan percieved ease of use akan berpengaruh terhadap meningkatnya keputusan pembelian pada toko pakaian online (Y) sebesar 0,152.

d. Nilai koefisien regresi kepercayaan bersifat positif sebesar 0,215, artinya variabel kepercayaan memiliki hubungan searah dengan keputusan pembelian dan setiap pertambahan satu satuan kepercayaan akan berpengaruh terhadap meningkatnya keputusan pembelian pada toko pakaian online $(\mathrm{Y})$ sebesar 0,215 .

\section{Uji Parsial (Uji t)}

Uji t merupakan uji dimana pengujian tersebut dilakukan untuk mengetahui apakah suatu hipotesis tersebut diterima maupun ditolak. Suatu hipotesis diterima apabila $\mathrm{t}$ hitung $\geq \mathrm{t}$ tabel.

\section{Tabel 2}

Hasil Uji t

\begin{tabular}{lccc}
\hline Model & t & Sig. & Keterangn \\
\hline Gaya Hidup & 4,171 & 0,000 & Berpengaruh \\
Percieved Ease Of Use & 3,206 & 0,002 & Berpengaruh \\
Kepercayaan & 2,586 & 0,013 & Berpengaruh \\
\hline Sur
\end{tabular}

Sumber: Olah data output SPSS 21, 2019 berikut:

Hasil untuk uji t dapat dilihat pada tabel 2 di atas, dapat dijabarkan sebagai

a. Nilai t hitung yang diperoleh variabel gaya hidup adalah 4,171 dengan nilai signifikan 0,000. Maka dapat disimpulkan bahwa t hitung > t tabel serta Sig. $\alpha<0,05$ yaitu 4,171 $>2,012$ serta $0,000<0,05$ yang berarti $\mathrm{H} 0$ ditolak dan Ha diterima. Dengan demikian variabel gaya hidup berpengaruh signifikan terhadap keputusan pembelian pada toko pakaian online.

b. Nilai t hitung yang diperoleh variabel percieved ease of use adalah 3,206 dengan nilai signifikan 0,002. Maka dapat disimpulkan bahwa t hitung $>\mathrm{t}$ tabel serta Sig. $\alpha<0,05$ yaitu 3,206 > 2,012 serta 0,002 < 0,05 yang berarti H0 ditolak dan Ha diterima. Dengan demikian variabel percieved ease of use berpengaruh signifikan terhadap keputusan pembelian pada toko pakaian online. 
c. Nilai t hitung yang diperoleh variabel kepercayaan adalah 2,586 dengan nilai signifikan 0,013. Maka dapat disimpulkan bahwa $\mathrm{t}$ hitung $>\mathrm{t}$ tabel serta Sig. $\alpha<0,05$ yaitu 2,586 2,012 serta 0,013 < 0,05 yang berarti H0 ditolak dan Ha diterima. Dengan demikian variabel kepercayaan berpengaruh signifikan terhadap keputusan pembelian pada toko pakaian online.

\section{Uji Signifikansi Model (Uji F)}

Untuk menjawab hipotesis ketiga $\left(\mathrm{H}_{3}\right)$ dalam penelitian ini dapat dilihat pada tabel 3 di bawah ini.

Tabel 3

Hasil Uji F

\begin{tabular}{lccc}
\hline Model & F & Sig. & Keterangan \\
\hline Regression & 54,251 & 0,000 & Berpengaruh \\
Residual & & & \\
Total & & & \\
\hline
\end{tabular}

Sumber: Olah data output SPSS 21, 2019

Nilai F hitung yang diperoleh dari tabel 3 di atas adalah sebesar 54,251 dengan nilai signifikan 0,000. Maka dapat disimpulkan bahwa $\mathrm{F}$ hitung $>\mathrm{F}$ tabel serta Sig. $\alpha>0,05$. Berdasarkan kriteria tersebut, terlihat bahwa 54,251>2,80 atau $\mathrm{F}$ hitung $>\mathrm{F}$ tabel yang dengan kata lain $\mathrm{HO}$ ditolak dan Ha diterima. Hal ini berarti Gaya Hidup $\left(\mathrm{X}_{1}\right)$, Percieved ease of use $\left(\mathrm{X}_{2}\right)$, Kepercayaan $\left(\mathrm{X}_{3}\right)$ berpengaruh secara simultan dan signifikan terhadap keputusan pembelian pada toko pakaian online $(\mathrm{Y})$.

\section{Hasil Uji Koefisien Determinasi}

Hasil Uji Koefisien Determinasi yang diuji dengan menggunakan program pengolah data SPSS 21 yang dapat dilihat pada tabel 4.

\section{Tabel 4}

Hasil Uji Koefisien Determinasi

\begin{tabular}{ccccc}
\hline Model & R & R Square & Adjusted R Square & Std. Error of the Estimate \\
\hline 1 &, $883^{\text {a }}$ &, 780 &, 765 & 1,931 \\
\hline
\end{tabular}

Sumber: Olah data output SPSS 21, 2019

Tabel 4 menunjukan bahwa nilai $R$ Square $=0,780$ berarti hubungan antara variabel bebas gaya hidup, percieved ease of use dan kepercayaan terhadap variabel terikat keputusan pembelian pada toko pakaian online sebesar 78\%. Nilai $R$ Square $=0,780$ berarti $78 \%$ variabel keputusan pembelian pada toko pakaian online dapat dijelaskan oleh variabel bebas gaya hidup, percieved ease of use, kepercayaan sedangkan sisanya $22 \%$ dijelaskan oleh variabel lain yang tidak diteliti dalam penelitian ini. 


\section{a. Pengaruh Gaya Hidup terhadap Keputusan Pembelian pada Toko Pakaian Online}

Hasil uji hipotesis pertama $\left(\mathrm{H}_{1}\right)$ menunjukkan nilai koefisien regresi sebesar 0,393 dengan nilai signifikansi yaitu $0,000<0,05$. Hal ini berarti Gaya Hidup berpengaruh signifikan terhadap keputusan pembelian pada toko pakaian online dengan arah positif. Ketika gaya hidup meningkat, maka keputusan pembelian juga akan meningkat, artinya semakin mewah gaya hidup seseorang akan meningkatkan keputusan pembelian, demikian juga sebaliknya, jika menurunnya gaya hidup seseorang maka menurun pula keputusan pembelian. Hasil penelitian ini sesuai dengan penelitian Wardoyo dan Andini (2017) yaitu gaya hidup berpengaruh signifikan terhadap keputusan pembelian. Sejalan dengan penelitian Anitha (2016) yaitu gaya hidup berpengaruh signifikan dan positif dalam pengambilan keputusan konsumen. Penelitian Long-Yi Lin dan Hsing-Yu Shih (2012) menunjukkan bahwa gaya hidup memiliki pengaruh positif yang signifikan terhadap keputusan pembelian.

\section{b. Pengaruh Percieved Ease Of Use terhadap Keputusan Pembelian pada Toko Pakaian Online}

Hasil uji hipotesis pertama $\left(\mathrm{H}_{2}\right)$ menunjukkan nilai koefisien regresi sebesar 0,152 dengan nilai signifikansi yaitu $0,002<0,05$. Hal ini berarti percieved ease of use berpengaruh signifikan terhadap keputusan pembelian pada toko pakaian online dengan arah positif. Artinya semakin tinggi percieved ease of use akan meningkatkan keputusan pembelian, demikian juga sebaliknya semakin rendah percieved ease of use maka keputusan pembelian akan menurun. Hasil ini sesuai dengan yang dilakukan penelitian oleh Andromeda (2014) yaitu adanya pengaruh secara positif kemudahan terhadap keputusan pembelian secara online. Sejalan dengan penelitian Ayuningtyas (2015) menyatakan percieved ease of use berpengaruh signifikan terhadap keputusan pembelian.

\section{c. Pengaruh Kepercayaan terhadap Keputusan Pembelian pada Toko Pakaian Online}

Hasil uji hipotesis pertama $\left(\mathrm{H}_{3}\right)$ menunjukkan nilai koefisien regresi sebesar 0,215 dengan nilai signifikansi yaitu $0,013<0,05$. Hal ini berarti kepercayaan berpengaruh signifikan terhadap keputusan pembelian pada toko pakaian online dengan arah positif. Artinya semakin tinggi kepercayaan akan meningkatkan keputusan pembelian, demikian juga sebaliknya semakin rendah kepercayaan maka keputusan pembelian akan menurun. Hasil penelitian ini sesuai dengan penelitian Anggraeni dan Madiawati (2016) yaitu kepercayaan berpengaruh signifikan terhadap Keputusan Pembelian online. Sejalan dengan penelitian Limpo dan Meryana (2017) menyatakan bahwa kepercayaan berpengaruh signifikan terhadap keputusan pembelian.

\section{d. Pengaruh Gaya Hidup, Percieved Ease Of Use dan Kepercayaan terhadap Keputusan Pembelian pada Toko Pakaian Online}

Hipotesis ketiga $\left(\mathrm{H}_{4}\right)$ dalam penelitian ini gaya hidup, percieved ease of use dan kepercayaan secara simultan berpengaruh signifikan terhadap keputusan pembelian pada toko pakaian online. Dari hasil pengujian untuk hipotesis keempat $\left(\mathrm{H}_{4}\right)$ ini, didapat bahwa nilai sig. pada pengujian hipotesis ini lebih kecil dari nilai alpha $(0,05)$ yaitu $0,000<0,05$. Begitu juga nilai $F$ hitung pada pengujian 
hipotesis ini lebih besar dibandingkan sengan nilai $\mathrm{F}$ tabel yaitu 54,251 > 2,80 sehingga untuk hipotesis keempat $\left(\mathrm{H}_{4}\right)$ diterima, yang berarti bahwa gaya hidup, percieved ease of use dan kepercayaan secara simultan berpengaruh terhadap keputusan pembelian pada toko pakaian online.

\section{SIMPULAN}

Dari hasil penelitan dan pembahasan yang telah dikemukanan di atas, maka dapat disimpulkan sebagai berikut:

1. Gaya hidup memiliki pengaruh yang signifikan terhadap keputusan pembelian pada toko pakaian online. Semakin mewah gaya hidup seseorang maka akan meningkatkan keputusan pembelian melalui situs belanja online hal ini dapat dilihat dari besarnya pengaruh yang diberikan oleh gaya hidup Ibu Rumah Tangga di Kecamatan Lubuk Begalung Kota Padang terhadap keputusan pembelian pada toko pakaian online.

2. Percieved ease of use memiliki pengaruh yang signifikan terhadap keputusan pembelian pada toko pakaian online. Dengan demikian tinggi rendahnya keputusan pembelian dipengaruhi oleh percieved ease of use. Semakin tinggi percieved ease of use akan meningkatkan keputusan pembelian, demikian juga sebaliknya semakin rendah percieved ease of use maka keputusan pembelian akan menurun.

3. Kepercayaan memiliki pengaruh yang signifikan terhadap keputusan pembelian pada toko pakaian online. Semakin tinggi kepercayaan akan meningkatkan keputusan pembelian, demikian juga sebaliknya semakin rendah kepercayaan maka keputusan pembelian akan menurun.

4. Gaya hidup, Percieved ease of use dan Kepercayaan memiliki pengaruh yang signifikan secara simultan terhadap keputusan pembelian pada toko pakaian online. Tinggi rendahnya keputusan pembelian dipengaruhi oleh Gaya hidup, Percieved ease of use dan Kepercayaan.

\section{DAFTAR PUSTAKA}

Andromeda, Kevin. 2014. Analisis Pengaruh Kepercayaan, Kemudahan, Dan Keragaman Produk Pakaian Via Online Terhadap Keputusan Pembelian Secara Online. Penelitian Ilmiah Universitas Muhamadiah Semarang.

Anggraeni, Penia dan Madiawati, Putu, N. 2016. Pengaruh Kepercayaan dan Kualitas Informasi Terhadap Keputusan Pembelian Secara Online Pada Situs www.traveloka.com. e-Proceeding of Management : Vol.3, No.2 Agustus 2016

Anitha. 2016. Influence Of Lifestyle On Consumer Decision Making With Special Reference To Organized Retail Formats In Chennai. Indian Journal of Commerce \& Management Studies, Volume VII Issue 1, Januari. 2016

Ayuningtyas, Dia. 2015. Pengaruh Perceived Ease Of Use, Enjoyment dan Trust Terhadap Keputusan Pembelian Pakaian Muslimah Secara Online. Jurnal Manajemen Update, Vol 4, No. 3. 
Davis, F.D., 1989. Perceived Usefulness, Perceived Ease Of Use, And User Acceptance Of Information Technology. MS Quarterly (online), Vol. 13 Iss. 3, pg. $319-340$.

Kotler, Philip and Kevin Lane Keller. 2012. Marketing Management 13. New Jersey: Pearson Prentice Hall, Inc.

Kusnandar, Deasy, Lestary., dan Kurniawan, D. (2018). Literasi Keuangan dan Gaya Hidup Ibu Rumah Tangga Dalam Membentuk Perilaku Keuangan Keluarga di Kota Tasikmalaya. Prosiding Seminar Nasional \& Call For Paper (SCA 8), 8(1).

Limpo, Lita dan Meryana. 2017. Effect of Trust and Easy on Decision Online Purchase toward Special Fashion Products. International Journal of Science and Research (IJSR), Vol, 6, Issue 10. October 2017.

Long-Yi Lin dan Hsing-Yu Shih. 2012. The Relationship of University Student's Lifestyle, Money Attitude, Personal Value and their Purchase Decision. Department of Business Administration Aletheia University, Taiwan ROC International Journal of Research in Management, Vol. 1 (January-2012).

Mowen, John C dan Michael Minor. 2011. Perilaku Konsumen. Jakarta: Erlangga.

Robbins SP, dan Judge. 2007. Perilaku Organisasi. Jakarta: Salemba Empat.

Sarwandi. 2016. Toko Online Modern dengan Opencart. Jakarta: Alex Media Komputindo.

Schiffman dan Kanuk. 2009. Perilaku Konsumen Edisi 7. Jakarta: Indeks

Sumarwan, Ujang. 2011. Perilaku Konsumen: Teori dan Penerapannya dalam Pemasaran. Bogor: Ghalia Indonesia. hlm. 165-166.

SWA. (2018, Oktober 12). Trik 66\% Konsumen Berbelanja Online Kategori Ibu dan Anak (online). Tersedia :https://swa.co.id/swa/trends/66-konsumenberbelanja-online-kategori-ibu-dan-anak.

Thoha, Miftah. 2012. Perilaku Organisasi; Konsep Dasar Dan Aplikasinya. Jakarta: Rajawali Pers.

Wardoyo dan Andini, Intan. 2017. Faktor-Faktor Yang Berpengaruh Terhadap Keputusan Pembelian Secara Online Pada Mahasiswa Universitas Gunadarma. Jurnal Ekonomi Manajemen Sumber Daya, Vol. 19, No. 1, Juni 2017. 